\title{
The Relationship Between Reading Interest and Figurative Language Mastery with Short Story Writing Skills
}

\author{
Nurzaiyanah ${ }^{1}$, Akmal Hamsa ${ }^{1}$, Kembong Daeng ${ }^{1}$ \\ ${ }^{1}$ Makassar State University, Indonesia
}

Received: October 15, 2021

Revised: November 16, 2021

Accepted: November 24, 2021

\begin{abstract}
This study aims to (1) prove a significant relationship between short story writing skills and reading interest. (2) proves a significant relationship between short story writing skills and mastery of figurative language. This type of research is quantitative research and the research design used is an expost facto correlational design. The data of this research are numerical data/nominal scores of interest in reading, mastery of figurative language and short story writing skills. Data collection techniques, namely questionnaire data to collect information on reading interest, multiple choice test data, and data on the assignment of writing short stories. The data analysis technique uses statistics that aim to determine the relationship between variables. The results obtained indicate that the results of the questionnaire analysis of students' reading interest get the category level with the highest frequency, which is in the high category. The results of the analysis of students' mastery of figurative language got the category level with the highest frequency, which was in the medium category. The results of the analysis of students' short story writing skills got the category level with the highest frequency, which was in the high category. There is a significant relationship between the variable of reading interest and short story writing skills with a significance value of 0.002 with a correlation coefficient of 0.437 , therefore the value of sig. $<0.05$ indicates a moderate positive relationship between reading interest and short story writing skills. There is a significant relationship between the variable mastery of figurative language and short story writing skills with a significance value of 0.002 with a correlation coefficient of 0.437 , therefore the value of sig. $<0.05$ indicates a moderate positive relationship between mastery of figurative language and short story writing skills.
\end{abstract}

Keywords: Interest in Reading, Figurative Language, Write Short Stories

\section{Introduction}

Teaching Indonesian is one of the means of pursuing the development and guidance of the Indonesian language in a directed manner. Learning Indonesian is one of the lessons that must be implemented in education in Indonesia. Learning Indonesian has four language skills that students must have, namely listening, speaking, reading and writing skills.

Indonesian language learning for secondary education is presented in a text-based book. Meanwhile, the structure of the text is a reflection of the structure of thinking. Thus, the more types of texts mastered by students, the more structures of thinking they can use in their social and academic life. In that way, students can construct their knowledge through the ability to analyze, associate, observe, question, and present the results of the analysis adequately.

The success of language teaching can be seen from the students' language skills and knowledge. Teaching Indonesian in schools basically aims to develop language skills. However, until now this goal has not shown maximum results, especially in writing skills. Writing is one of the language skills that has a higher level of difficulty compared to other skills. Writing requires skills, broad insight and strong motivation to do so. 
Many factors affect students' writing skills, both internal and external factors. Internal factors, namely diction mastery, vocabulary mastery, sentence structure mastery, reading interest, writing interest, learning achievement talent, mental and so on. External factors, namely learning methods, completeness of existing books in schools, environment and curriculum. Once the importance of writing, then as educators must be able to provide examples and provide support to students to write often. One aspect of writing skills is writing short stories or often known as short stories.

Literary appreciation is related to linguistic and non-linguistic content contained in literary works. One of the steps in literary appreciation is retelling through oral or written. In this case, it relates to students' skills in writing literary works, for example the form of prose literary works. According to its content, prose is divided into two, namely prose fiction and non-fiction. In this study, the researcher focuses more on prose fiction, namely short stories.

A short story is a type of prose whose contents are not real events and come from imagination. The number of words in the short story is no more than ten thousand words and uses a narrative style, concise and straight to the core of the story. Short stories are one of the materials taught at the upper secondary level, especially in class XI. In short story material, students are required to understand the structure and rules of the text, compare the text, analyze the text and evaluate the text.

In learning to write in high school (SMA), the element that needs to be considered after discourse is paragraphs. In addition, learning to write cannot be separated from the practice of developing paragraphs. Through writing skills students will better understand and convey ideas, feelings, desires, experiences, and appreciation.

Writing short stories is very important in schools because through short story writing activities, students not only practice developing their imagination and thinking skills, but also practice their ability to use figurative language and Indonesian well. Therefore, in achieving the learning objectives of short story writing skills, learning planning must be carried out optimally so that learning objectives can be achieved.

The skill of writing short stories is one form to improve the ability of students to appreciate literary works. Literary material must foster student appreciation of literary works (Walker, 1966). Appreciating literature is knowing, understanding, living and enjoying literary works. Literature lessons direct students to become people who like literary works, willing to read literary works themselves so that they can absorb values, especially moral values contained in literary works.

Writing short stories, not only relying on reading experience which is then poured into a literary work such as short stories. But what needs to be considered is the language used in writing short stories. Therefore, it takes concentration, willingness and interest in reading short stories to gain more knowledge of the contents of short stories. In this case, the psychological aspect plays a very important role in motivating students to do reading activities. One of these aspects is "interest". Interest in reading literary works, especially reading short stories, is one aspect that determines students' ability to appreciate and write short stories.

Literature appreciation activities need to be given to students, especially high school / MA / vocational students, because one of the goals of teaching literature in high schools that is not easy to achieve is appreciation and students' understanding of literature. In the syllabus of Indonesian Language and Literature subjects for class X and class XI, there are basic competencies, namely analyzing the values contained in short stories or appreciating short stories. However, the reality that appears now is that in learning Indonesian in literary material, especially appreciating short stories at the SMA/MA level, the interest of students in reading short stories is very lacking. In fact, reading short stories is needed by students. 
The lack of interest in reading by students towards reading, especially reading in the form of literature, greatly affects the lack of students' ability to express their imaginative ideas through writing, as a result, students tend to find it difficult to compose a literary work. So that students do not experience these difficulties, students are encouraged to read a lot of reading material in the form of literature. The process of writing short stories will run smoothly if accompanied by interest (Bartan, 2017; Pardede, 2010). Therefore, teachers need to arouse students' interest so that the lessons given are easily understood by students.

Many benefits are obtained from reading a literary work, especially short stories, one of which is the language used in short stories. Reading short stories is an activity that indirectly students can master a language that not everyone understands. This language is a figurative language or style of language that is widely found in literary works, especially short stories.

Mastery of figurative language is very important in reading a literary work, especially short stories so that the process of reading short stories goes well. Figurative language is a linguistic aspect that makes a literary work more interesting to read, especially for literary connoisseurs.

Mastery of figurative language can support the writing of a literary work, especially short stories. In producing a short story, it not only displays an interesting plot and plot, but also the language used to make it more interesting to read. By mastering figurative language, students will find it easier to string words in making short stories.

The cause of students in Class XI MA Alkairaat Siniu not being interested in reading short stories is not only due to the boring learning process but also the influence of technology and the environment so that students are rarely or not interested in reading literary works, especially reading short stories. In this case, students can take advantage of technology by gaining more knowledge, especially short stories. But the reality is different, students only watch and read other things that are viral by displaying various kinds of shows.

The short story writing skills of students at MA Alkhairaat siniu have not shown satisfactory results. Students are less interested in writing short stories. This can be seen in the results of writing short stories for students who on average get unsatisfactory scores so that many students in Class XI take remedial measures in order to get good results and fulfill the requirements for writing short stories. Another factor that affects students' lack of short story writing skills is the lack of interest in reading. Students need to know that a lot of reading can add insight, ideas, knowledge about life and so on, making it easier for students to write an essay, especially short stories.

\section{Literature Review}

\section{Learning Indonesian Language and Literature}

The learning process in the 2013 Curriculum includes five main learning experiences, namely observing, asking questions, gathering information, associating, communicating and creating. Literature learning is a two-way activity carried out by teachers and students in order to teach literature to students.

Based on the curriculum, language and literature learning in schools is listed with the aim that all students have a basis for appreciating and appreciating literary works, both poetry, short stories, translated novels, local novels, saga, rhymes, and so on (Juanda \& Azis, 2019).

Suryaman (2010) argues that literary appreciation is defined as an activity to engage in literary creativity in earnest to grow understanding, appreciation, sensitivity to critical thinking and sensitivity to good feelings towards literary ideals. In relation to learning objectives, the appreciation process is divided into four levels, namely the level of liking, enjoying, reacting, and the level of producing (Wardani, 2001). 


\section{Short Story Writing Skills}

According to Nurgiyantoro (2013) A short story is a story that is finished reading in one sitting, about half an hour to two hours, something that would be impossible in a novel. Short stories tend to be dense and to the point compared to longer works of fiction, such as novellas (in the modern sense) and novels (Setiarini \& Artini, 2017).

Succinctly, Jabrohim (1994) provides the main characteristics of the short story: Fiction, Short and concise form, The story is centered on one event/incident/conflict of characters, Limited number and development of actors, The whole story gives a single effect/impression.

According to Setiarini \& Artini (2017) The short story has 2 elements, namely: intrinsic elements and extrinsic elements. (1) Intrinsic elements are elements that build the work itself: Theme, setting, plot (plot), character/characterization, point of view, namely the position of the author in presenting the story, style of language, value (mandate), message or advice to be conveyed author through stories. (2) Extrinsic elements are elements that are outside the literary work, but indirectly affect the building or system of the organism of the literary work.

\section{Short Story Writing Skills with Interest in Reading}

Erwin (2014) states that "A person is able to write well because of the extensive experience gained through reading. A strong interest in reading short stories will affect the ability to write short stories. After students are able to understand well, students will easily write short story (Wulan, 2018). Tidjan (1977) states that a lack of interest in reading can lead to an inability to interpret reading. Likewise, the inability to interpret reading can lead to a lack of interest in reading.

\section{Short Story Writing Skills and Figurative Language}

A literary work looks beautiful due to the style of language. Lusita (2018) "Style or language style is used by the author to express what is on his mind and is poured into a writing as attractively as possible. The style is contained in all texts, not a particular language, not merely literary texts., in this case style is a standard feature of language, and style is a way of expression". Short stories include literary works that tell something in a succinct way. Actually, short stories do not only present brief problems, but also display a variety of language styles.

Figurative Language According to Lusita (2018) defines figurative language as the most dominant literary rhetoric. Figurative language is the author's way of using language to obtain an aesthetic effect by figuratively expressing ideas that suggest literal meaning. In addition, Nurgiyantoro (2013) argues that the term figurative language is another term from figurative language, figurative language is a language expression technique, stylistic, whose meaning does not refer to the literal meanings that support it, but to the added meaning or implied meaning.

The term figurative is well known and has been used by the Roman novelists Cicero and Suetonius with the term figura which means 'shadow, image, satire, allegory' (Tarigan, 2010). Abrams (2010) states that figurative language is part of a rhetorical style of language. According to Setiarini \& Artini (2017) figurative language or figure of speech can be classified into four major groups, namely comparison, contradiction, satire and affirmation

\section{Methods}

This type of research is quantitative research and the research design used is an expost facto correlational design. The population in this study were students of Class XI MA Alkhairaat Siniu in the year totaling 50 students spread over three classes. The sample in this study were all students of Class XI IPA and XI IPS totaling 50 students. The variables in this study are one dependent variable which is symbolized by $\mathrm{Y}$, namely short story writing skills, and two independent variables are represented by $\mathrm{X} 1$, namely reading interest and $\mathrm{X} 2$, namely mastery 
of figurative language. The data of this research are numerical data/nominal scores of interest in reading, mastery of figurative language and short story writing skills. The instruments in this study are: (1) Reading Interest Instruments, using a questionnaire or questionnaire. (2) Figurative Language Mastery Instrument, namely through an objective test in the form of multiple choice. (3) Short Story Writing Skills Instrument, namely the assignment of writing short stories. Data collection techniques, namely questionnaire data to collect information on reading interest, multiple choice test data, and data on the assignment of writing short stories. The data analysis technique uses statistics that aim to determine the relationship between variables.

\section{Results and Discusssion}

This chapter discusses in detail the results of research on the Relationship between Reading Interest and Figurative Language Mastery with Short Story Writing Skills for Class XI Students of MA Alkhairaat Siniu, Central Sulawesi. This research is a correlation research that wants to know whether there is a relationship between reading interest with short story writing skills and figurative language with short story writing skills.

\section{Description of the Results of Reading Interest Data Analysis}

In this study, the questionnaire aims to collect information on students' reading interest. The questionnaire sheet will include a combination of statements for students on reading interest. The reading interest test of 50 students depicted that the average score obtained by students was 83.75 , the highest score was 88.75 obtained by three students and the lowest score was 73.75 obtained by two students.

A very high score of 88.75 was obtained by three students with a sample code of $003,009,045$; a score of 87.5 was obtained by four students with a sample code of $001,007,037,049$; the value of 86.25 was obtained by two students with a sample code of 013,033 ; a score of 85 was obtained by one student with a sample code of 032. In filling out the questionnaire (questionnaire number) some students chose to check the "good" checklist so that they got a score of three.

A high score of 83.75 was obtained by eight students with a sample coefficient of 011,019 , 022, 023, 031, 034, 036, 041; a score of 82.5 was obtained by four students with a sample code of 014, 020, 030, 048; a score of 81.25 obtained by seven students with sample codes 006, 012, 015, 016, 017, 029, 046; a score of 80 was obtained by seven students with a sample code of $010,024,027,035,038,044,047$. In filling out the questionnaire/questionnaire (questionnaire number) some students chose to check the "good" checklist so that they got a score of three.

The average score is 78.75 obtained by two students with a sample code of 043,050 ; a score of 77.5 obtained by four students with sample codes $002,021,026,040$; a score of 75 was obtained by six students with a sample code of 004, 008, 025, 028, 039, 042. In filling out the questionnaire/questionnaire (questionnaire number) some students chose to check the "good" checklist so they got three points. A low score of 73.75 was obtained by two students with a sample code of 005,018 . In filling out the questionnaire/questionnaire (questionnaire number) some students chose to check the "good" checklist so that they got a score of three.

Through frequency distribution analysis data and presentations, the students' reading interest scores from the highest to the lowest score. The highest score of 88.75 was obtained by three students $(6.5 \%)$, the score of 87.5 was obtained by four students $(8.6 \%)$, the score of 86.25 was obtained by two students (4.2\%), the score of 85 obtained one student $(2.0 \%)$, a score of 83.75 obtained by eight students $(16.4 \%)$, a score of 82.5 obtained by four students $(8.1 \%)$, a score of 81.25 obtained by seven students ( $13.9 \%$ ), a score of 80 was obtained by seven students (13.7\%), a score of 78.75 was obtained by two students $(3.8 \%)$, a score of 77.5 was obtained 
by four students (7.6\%), the 75 obtained by six students (11.0\%) and the lowest score is 73.75 obtained by two students $(3.6 \%)$.

The minimum score obtained by students is 73.75 and the maximum value obtained by students is 88.75. The average value of students is 7.4. So the results of the analysis above say that the 50 students who were sampled were only 48 who scored above 75 . and the sample who scored 75 and below amounted to two people.

\section{Description of the Results of Figurative Language Mastery Data Analysis}

This research is in the form of a test to measure the ability of students in mastering figurative language. This test is in the form of multiple choice questions with a total of 30 questions.

Figurative language mastery test of 50 students depicted that the average score obtained by students is 70 , the highest score is 80 obtained by eight students and the lowest score is 63 obtained by one student.

A high score of 80 was obtained by eight students with sample codes 003, 007, 009, 031, 033, 036, 043, 046; a score of 76 was obtained by five students with a sample code of 001, 013, 020, 037,049 .

The average score of 73 was obtained by twelve students with sample codes $005,006,008,014$, 016, 022, 023, 027, 038, 040, 041, 048; a score of 70 was obtained by fourteen students with a sample coefficient of 002, 004, 011, 015, 018, 019, 021, 024, 029, 034, 039, 042, 044, 047.

A low score of 67 was obtained by ten students with sample codes 010, 012, 017, 025, 026, 028, 032, 035, 045, 050; a value of 63 was obtained by one student with a sample code of 030 .

Through data analysis of frequency distribution and presentation, the acquisition of students' figurative language mastery scores from the highest to the lowest score. The highest score of 80 was obtained by eight students (17.3), the score of 76 was obtained by five students (10.27\%), the score of 73 was obtained by twelve students (23.6\%), the score of 70 was obtained by fourteen students ( $26.49 \%), 67$ obtained by ten students $(20.5 \%)$, and the lowest score is 63 which is obtained by one student $(1.70 \%)$.

The minimum score obtained by students is 63 and the maximum value obtained is 80 students. The students' average score is 8.13 . So the results of the analysis above say that the 50 students who were sampled were only 39 who scored above 70 . And the sample who scored 70 and below amounted to 11 people.

\section{Description of the Results of Data Analysis of Short Story Writing Skills}

In collecting data on short story writing skills, namely by giving assignments, students will be directed to be able to write a short story.

A very high score of 93 was obtained by one student with a sample code of 009 ; the value of 89 was obtained by two students with a sample code of 001, 007, 036; the value of 86 was obtained by four students with sample codes 010, 014, 038, 045 .

A high score of 82 was obtained by six students with sample codes $013,015,016,018,019$, 044; A score of 78 was obtained by ten students with a sample coefficient of 004, 006, 021, 026, 033, 037, 039, 041, 042, 048; a score of 75 was obtained by six students with a sample code of 008, 020, 011, 034, 043, 049 .

The average score of 71 was obtained by ten students with sample codes $005,007,012,025$, 030, 031, 032, 040, 047, 050; a score of 68 was obtained by three students with a sample code of $022,027,035$. 
The low score is 64 obtained by four students with sample codes $002,017,020,029$; a score of 57 was obtained by one student with a code of 023 ; the value of 53 was obtained by three students with codes $003,024,028$.

Through frequency distribution analysis data and presentations, the acquisition of students' figurative language mastery scores from the highest to the lowest score. The highest score of 93 was obtained by one student (2.4\%), the score of 89 was obtained by two students $(4.7 \%)$, the value of 86 was obtained by four students (9.2\%), the score of 82 was obtained by six students (13.2\%), a score of 78 was obtained by ten students (20.9\%), a score of 75 was obtained by six students $(12.0 \%)$, a score of 71 was obtained by ten students $(19.0 \%)$, a score of 68 was obtained by three students $(54 \%)$, the score of 64 was obtained by four students $(6.8 \%)$, the score of 57 was obtained by one student (1.5\%), and the lowest score of 53 was obtained by three students $(4.2 \%)$.

The minimum score obtained by students is 53 and the maximum value obtained by students is 93. The average value of students is 7.44 . So the results of the analysis above say that the 50 students who were sampled were only 29 who scored above 75 . and the sample who scored 75 and below amounted to 21 people.

\section{Research Results of Interest in Reading, Mastery of Figurative Language with Short Story Writing Skills}

The research was conducted to see the relationship between reading interest and mastery of figurative language with short story writing skills.

Based on the results of the questionnaire analysis of students' reading interest, it was found that the category level with the highest frequency was in the high category. The results of the analysis of students' mastery of figurative language were found that the category level with the highest frequency was in the medium category. The results of the analysis of students' short story writing skills were found that the category level with the highest frequency was in the high category.

Table 1. The results of the analysis of students' short story writing skills

\begin{tabular}{|c|c|}
\hline Coefficient Interval & Relationship Level \\
\hline $0,00-0,199$ & Very low \\
\hline $0,20-0,399$ & Low \\
\hline $0,40-0,599$ & Currently \\
\hline $0,60-0,799$ & Strong \\
\hline $0,80-1,000$ & Very strong \\
\hline
\end{tabular}

Source: Suqiyono (2013)

\section{The Relationship between Reading Interest and Short Story Writing Skills}

Based on the results of the study, there was a significant relationship between the variables of reading interest and short story writing skills with a significance value of 0.002 with a correlation coefficient of 0.437 , therefore the value of sig. $<0.05$. To find out the relationship between reading interest and short story writing skills, it was obtained by processing SPSS data that had been analyzed.

Based on the findings in the study, there was a moderate positive relationship between reading interest and short story writing skills. From these findings it can be concluded that if students have a high interest in reading, their short story writing skills will be better. 


\section{The Relationship between Figurative Language Mastery and Short Story Writing Skills}

Based on the results of the study, there was a significant relationship between the variables of figurative language mastery and short story writing skills with a significance value of 0.002 with a correlation coefficient of 0.437 , therefore the value of sig. $<0.05$. To find out the relationship between mastery of figurative language and short story writing skills, it was obtained by processing SPSS data that had been analyzed.

Based on the findings in the study, there was a moderate positive relationship between mastery of figurative language and short story writing skills. From these findings it can be concluded that if students master figurative language, their short story writing skills will be better

\section{Conclusion}

Based on the results of the study, there was a significant relationship between the variables of reading interest and short story writing skills. The findings in the study showed that there was a moderate positive relationship between reading interest and short story writing skills. Based on the results of the study, there was a significant relationship between the variables of mastery of figurative language and short story writing skills. The findings in this study indicate that there is a moderate positive relationship between mastery of figurative language and short story writing skills.

\section{References}

Abrams. (2010). A Glosary In Literary Terms. New York: Holt, Rinehart and Winston.

Bartan, Ö. Ş. (2017). The effects of reading short stories in improving foreign language writing skills. The Reading Matrix: An International Online Journal, 17(1), 59-74.

Erwin. (2014). Hubungan Antara Minat Membaca Karya Sastra dengan Kemampuan Menulis Cerpen Pada Siswa Kelas X SMA N 1 Samba. Jurnal Pendidikan dan Pembelajaran Khatulistiwa. 3(7).

Jabrohim. (1994). Pengajaran Sastra. Yogyakarta: Pustaka Pelajar.

Juanda \& Azis. (2019). Materi Ajar Cerpen di SMA dengan Tema Lingkungan Berdasarkan Kurikulum 2013. Prosiding Seminar Nasional Lembaga Penelitian Universitas Negeri Makassar. ISBN: 978-602-5554-71-1.

Lusita, K. (2018). Analisis Diksi, Bahasa Figuratif, dan Citraan Serta Nilai Pendidikan Karakter Dalam Kumpulan Cerpen Perempuan Yang Disunting Gelombang Karya Indra Traggono. Jurnal Keilmuan Bahasa, Sastra, dan Pengajarannya. 1(2).

Nurgiyantoro, B. (2013). Penilaian dalam Pengajaran Bahasa dan Sastra. Yogyakarta: BPFE.

Pardede, P. (2010). Short stories use in language skills classes: Students' interest and perception. In Proceedings of the 4th International Seminar. Bringing Linguistics and Literature into EFL Classrooms (pp. 1-17).

Setiarini, I. W. \& Artini, MG. S. (2017). Bahasa Indonesia 2. Jakarta Timur: Perpustakaan Nasional.

Suryaman, M. (2010). Strategi Pembelajaran Sastra. Yogyakarta: PBSI FBSUNY.

Tarigan, H. G. (2010). Prinsip-Prinsip Dasar Sastra. Bandung: Angkasa.

Tidjan. (1977). Bimbingan Konseling di Sekolah Menengah. Yogyakarta: Swadaya.

Walker, J. L. (1966). Fostering literary appreciation in junior high school. The English Journal, 55(9), 1155-1220. 
Wardani. (2001). Sistem pembelajaran Bahasa Indonesia. Jakarta: Pusat Penerbitan Universitas Terbuka.

Wulan, P. (2018). Pengaruh Minat dan Motivasi Membaca Terhadap Kemampuan Menulis Cerpen Siswa Kelas XII SMK Negeri 9 Samarinda. Jurnal Ketatabahasaan dan Kesusastraan. 13(1). 